\title{
LETRAMENTO E INCLUSÃO: DO ESTADO-NAÇÃO À ERA DAS TIC*
}

(Literacy and inclusion: from the nation-state to the age of ICT)

\author{
Marcelo El Khouri BuZATo \\ (UFGD/Unicamp)
}

\begin{abstract}
RESUMO: O trabalho objetiva (i) propor uma concepşão relacional de letramento digital, alternativa às encontradas na literatura corrente, (ii) fundamentar a necessidade de tal concepşãa em uma análise sócio-histórica da relação entre inclusão, tecnologia e letramento, e (iii) ilustrar a utilidade de tal concepção para a pesquisa em inclusão digital no âmbito do campo aplicado dos estudos da linguagem. A fundamentação teórica abrange estudos sobre inclusão digital e letramento digital, teorias de letramento de cunbo sócio-cultural e teorias de inclusão social com respeito às diferenças, todas, de alguma forma, postas em relação com a concep̧̧ão dialógica da linguagem. Utilizam-se vinhetas de situaçôes reais para ilustrar o poder operativo da teoria proposta. Concluise que a concep̧cão de letramento digital defendida abre um campo alternativo de pesquisa em inclusão digital, mas exige um posicionamento ético condizente com uma concep̧̧ão de inclusão fundada na agentividade e na autonomia dos sujeitos na transculturalidade. PaLAVRAS-CHAVE: letramento digital; alfabetização digital; inclusão digital; globalização.
\end{abstract}

ABSTRACT: The aims of this paper are (i) to propose a relational concept of digital literacies as an alternative to the ones found in the current literature, (ii) to justify the need for such a conception on the grounds of a socio-historic analysis of the relations among literacy, technology and inclusion, and (iii) to illustrate the usefulness of such a conception for research on digital inclusion within the field of applied language studies. The theoretical foundations comprise studies in digital literacies and digital inclusion, sociocultural theories of literacy, and multicultural theories of social inclusion, all of which are brought to relate to the dialogic conception of language. Vignettes taken from real situations are used to illustrate the operative potential of the theory. It is concluded

* O presente trabalho foi realizado com o apoio do UOL (www.uol.com.br), através do Programa UOL Bolsa Pesquisa, processo número 20060509140453a.

D.E.L.T.A., 25:1, $2009(1-38)$ 
that the proposed conception of digital literacies opens an alternative field of research in digital inclusion, but it demands an ethical stance that is congruous with a notion of inclusion founded on the agency and autonomy of social subjects in the face of transculturality.

KEY-WORDS: literacy; digital literacies; digital inclusion; globalization.

\section{Introdução}

O termo inclusão digital tenta expressar a noção já tradicional, embora controversa, de que certos meios e/ou tecnologias podem ser aplicados de maneira planejada, eficaz e previsível ao desenvolvimento social. O qualificador "digital" aparece nessa expressão para ressaltar o fato de que, em anos recentes, uma gama ampla de sentidos do desenvolvimento tem sido associada às Novas Tecnologias da Informação e da Comunicação (doravante TIC). Essas, por sua vez, têm sido vistas como "chaves para o crescimento, empregos, investimento e inovação" uma vez que "um uso mais amplo e eficiente das TIC por todos os setores da economia é uma clara oportunidade de fomento da competitividade, do desenvolvimento sustentável e da inclusão social” (Reding 2006: 2, minha tradução).

Grosso modo, duas condições para a inclusão ${ }^{1}$ digital têm sido apontadas como essenciais, quando não como suficientes, na literatura: o acesso à infra-estrutura técnica mínima (computadores, software e serviços de conexão à Internet) e um grau mínimo de capacitação da população para o uso das TIC.

O presente trabalho toma como axioma a idéia de que toda visão de inclusão (social, digital) é subsidiada por uma certa concepção de lingua-

\footnotetext{
1 Tomar o termo inclusão digital com o propósito de descrever o tema desse trabalho não significa concordar com o seu sentido no senso comum. Quem fala em inclusão, fala, na maior parte dos casos, do lugar de incluído, isto é, fala como alguém que se vê pertencendo a um contexto estável, homogêneo e fechado, dentro do qual o objetivo ou ideal que termos desgastados como "cidadania" ou "justiça social" tentavam descrever no passado já teria sido plenamente alcançado. Mais do que isso, fala como alguém que já definiu aquilo que é, tem ou faz como bom e necessário para todos. Inclusão é, portanto, uma palavra que muito facilmente desliza para o sentido de hegemonia, isto é, para um processo de subordinação de significados, valores e crenças das classes subservidas pelo país aos das classes que dele se servem. Não é desse lugar que pretendo falar, mesmo sabendo que em alguma medida isso é inevitável, justamente por ser quem sou (branco, classe média, heterossexual, professor universitário, cidadão).
} 
gem (Buzato 2007a), assim como por um certo conjunto de práticas sociais a ela relacionadas, sendo que ambas, linguagem e práticas, não apenas refletem os sistemas sociais nos quais existem, como também os refratam continuamente (Bakhtin 1998, 2003; Certeau 1984).

Assim como uma visão de linguagem é também uma visão de inclusão, também a toda visão ou modelo de letramento estão atreladas uma concepção de linguagem e uma concepção de sociedade. Por exemplo, uma concepção de letramento como uma variável autônoma, determinante de impactos cognitivos e socioculturais nos indivíduos e grupos que o praticam, está diretamente ligada a uma visão da linguagem fundamentada num objetivismo abstrato que separa o sistema lingüístico de seus usos. Congruente com essa concepção - ou subjacente a ela - está a noção de que a sociedade é ou deve ser homogênea, e de que a heterogeneidade dos contextos, dos sujeitos e dos letramentos conta como handicap para o desenvolvimento social.

A visão de inclusão que me orienta toma como base a concepção bakhtiniana de dialogismo e, por conseqüência, a relação intrínseca existente entre sujeito e língua. Explicando melhor, considero que o falante aquele que se inclui numa comunidade discursiva, ou num espaço social de seu interesse através da língua - não é um atualizador de um sistema que não lhe é possível alterar (ou que lhe assujeita), nem, tampouco, a origem ou a fonte absoluta e independente do seu dizer. Ele é, por um lado, um ser histórico, aberto (em processo contínuo de construção de sua identidade) e imerso no diálogo e, por outro, alguém que se apóia/depende, em alguma medida, do sistema lingüístico num dado momento para estabelecer a ponte, o contato com o outro. Cada um de seus enunciados só obtém acabamento a partir da réplica do outro - e não do mero acesso ao sistema. Por isso, trata-se de um sujeito do diálogo e, portanto, capaz de abertura. É, sobretudo, alguém que responde ativamente às replicas que o interpelam, impregnando a língua com seu próprio horizonte apreciativo, sua própria expressividade. (Bakhtin 1994)

Assim, a questão que inspira a reflexão proposta neste artigo é: que concep̧̧ão ou modelo de letramento digital pode ser postulada como congruente com essas visões de linguagem e de inclusão, assim como com o momento sócio-histórico em que se dá o que chamamos de inclusão digital? Para começar a pensar sobre isso, convido o leitor a refletir comigo a respeito de como linguagem, tecnolo- 
gia e sociedade têm aparecido entrelaçados nas práticas de leitura e escrita, e como essas práticas têm sido usadas para legitimar visões de inclusão no período que vai desde a gênese do Estado-nação (modernidade ilustrada, capitalismo industrial) até o ápice da globalização (modernidade tardia, capitalismo em rede). Mas, antes, é necessário esclarecer, ao menos provisoriamente, a que me refiro pelo termo letramento digital.

\section{Alfabetização ou letramento?}

A razão pela qual temos necessariamente que pensar em letramento quando refletimos sobre inclusão digital não é tão trivial quanto pode parecer à primeira vista. Não se trata apenas de reconhecer que o acesso às TIC pressupõe a capacidade de receber e produzir informações por meio de dispositivos digitais, algo que a compreensão leiga de inclusão digital costuma denominar "alfabetização digital". Trata-se de ampliar qualitativamente o debate sobre inclusão e tecnologia, contrastando a idéia mais restrita de alfabetização com a noção mais ampla e socialmente significativa de letramento.

O que se quer dizer com alfabetização digital nos estudos de inclusão digital pode variar bastante tanto entre diferentes contextos disciplinares em que o termo aparece, como dentro de um mesmo trabalho complexo, realizado por um grupo de autores. Este é o caso, por exemplo, do Livro Verde da Sociedade da informação ${ }^{2}$, no qual veremos que a alfabetização digital aparece definida ora como "processo de aquisição de habilidades básicas para o uso de computadores, redes e serviços de Internet” (glossário), ora como "a aquisição de habilidades básicas para o uso de computadores e da Internet, mas também que capacite as pessoas para a utilização

2 O Livro Verde é um documento que reúne as diretrizes do Programa Sociedade da Informação (SocInfo), do ministério da Ciência e Tecnologia, o qual visa "integrar, coordenar e fomentar ações para a utilização de tecnologias de informação e comunicação, de forma a contribuir para a inclusão social de todos os brasileiros na nova sociedade e, ao mesmo tempo, contribuir para que a economia do País tenha condições de competir no mercado global." (http://www.socinfo.org.br/sobre/ programa.htm, 0/05/2005). É importante notar que o Livro Verde não utiliza sequer uma vez o termo "inclusão digital", embora apareça na formulação de seus objetivos a expressão "inclusão social". A atenção para este fato, assim como para as contradições relativas à noção de alfabetização digital existentes dentro do Livro Verde, me foi aponta por Maria Helena Silveira Bonilla, a quem agradeço. 
dessas mídias em favor dos interesses e necessidades individuais e comunitários, com responsabilidade e senso de cidadania" (Takahashi 2000: 31; ênfases adicionadas).

No capítulo dedicado à Educação desse mesmo documento oficial, à alfabetização digital é reservada a noção de aquisição de um nível rudimentar de capacitação dos sujeitos para o uso das TIC no país, que não contempla as possibilidades de sua aplicação pelos brasileiros nos diferentes campos produtivos da economia, da construção de conhecimento e das dinâmicas culturais, nem, tampouco, da geração de tecnologias próprias pelos brasileiros. Ressalvam, então, os autores, que uso, aplicação e geraçãa só serão contemplados a partir da integração das TIC, como meio e como objeto, aos processos educativos de níveis médio, superior e pós-graduado. Nesse sentido, contrapõem ao conceito de alfabetização digital o de fluência em TIC, definido como capacidade de reformular conhecimentos, expressar-se criativa e apropriadamente, bem como produzir e gerar informação em vez de meramente compreendê-la.

Independentemente de considerações mais rigorosas a respeito dos sentidos técnicos de alfabetização ou fluência, a própria flutuação nos termos que pretendem definir as capacidades necessárias para a prática social das TIC pela população aponta para uma consciência emergente, se não ainda totalmente formulada, de que a inclusão digital, se entendida como dependente do uso, transformação e aplicação das TIC em favor de interesses e necessidades do país, requer muito mais do que acesso e capacitação básica. Daí a necessidade/oportunidade de pensar-se em letramento(s) digital(is).

Com essa breve discussão, não pretendo policiar as escolhas lexicais dos que tomam a inclusão digital como objeto de estudo ou de ação política, mas apenas apresentar o argumento central deste trabalho: a relação entre inclusão e linguagem na era das TIC é melhor abordada como uma questão de letramento, com todas as implicações daí decorrentes. Partirei, em direção a esse objetivo, da concepção de letramento proposta por Kleiman (1995:19). A autora define letramento como "um conjunto de práticas sociais que usam a escrita, enquanto sistema simbólico e enquanto tecnologia, em contextos específicos, para objetivos específicos". Ao longo do artigo, utilizarei o termo letramento tanto no singular quanto no plural. Quando no singular, denotará o fenômeno em seu aspecto histórico e/ ou macrossocial, ou caracterizado como um processo de aquisição da escri- 
ta em suas diferentes formas. Quando no plural, denotará tanto os diferentes conjuntos de práticas e tecnologias associados à construção de sentidos compartilhados socialmente (Barton 1994), quanto aos diferentes significados e funções dessas práticas em contextos socioculturais diversos (Street, 1984).

\section{Perspectivas históricas de letramento e inclusão}

\section{A era do estado-nação}

A argumentação que apresento a seguir toma como ponto de partida um momento histórico da relação entre linguagem, tecnologia e inclusão que se estende do final do século XVIII a meados do século XX: a gênese e implantação do Estado-nação. Urdido no bojo da modernidade ilustrada e das revoluções burguesas, e impulsionado pelo industrialismo (Castells 1999), o projeto político do Estado-nação consistia basicamente na implantação de novas formas de identificação e pertencimento capazes de garantir a coesão de formações socioculturais lingüisticamente heterogêneas fixadas em um mesmo território. Tais populações, entretanto, raramente foram tornadas leais ao Estado por meios pacíficos.

Nesse processo, a língua e as tecnologias em torno dela foram fatores cruciais para um certo tipo de inclusão que pressupunha unificação política e homogeneização cultural. Segundo Habermas (2002:157),

\footnotetext{
foi apenas uma consciência nacional propagada por intelectuais e sábios, que se espraiou lentamente a partir da burguesia urbana culta e se cristalizou em redor da ficção de uma ascendência comum, da construção de uma história compartida e de uma língua escrita, gramaticalmente simplificada, aquilo que certamente transformou os súditos em cidadãos politicamente conscientes, que se identificam com a constituição da república e com seus fins declarados.
}

A reconfiguração da relação entre linguagem, identidade e cidadania no Estado-nação incluiu, portanto, a emergência da noção de língua nacional, objeto de coerções e regulações estatais que alçam ao status de padrão uma língua ou dialeto de prestígio dentro de um espaço geográfico delimitado. Direta ou indiretamente, essa mesma reconfiguração institui no domínio da modalidade escrita da língua nacional uma pré-condição para o exercício da cidadania, fundamentada e defendida agora com base na letra da Lei. 
A gênese do Estado-nação é marcada, portanto, pela manifestação de forças de centralização verbo-ideológica impulsionadas por um acoplamento entre o Estado burguês emergente e um ideal identitário unificado, forças às quais podemos, com Bakhtin (1988), chamar de centrípetas. Tais forças unificantes e estabilizadoras necessitavam servir-se de uma base material/ tecnológica para fixar ou cristalizar a norma, de modo que a língua nacional fosse capaz de resistir aos processos naturais de descentralização e desunificação que, novamente com Bakhtin (1988), podemos chamar de forças centrífugas. Além disso, era preciso encontrar maneiras de transportá-la intacta, na forma de textos, através das redes de circulação de bens e pessoas que iam territorializando o espaço em que a língua única passaria a vigorar como pressuposto da cidadania.

Disponível para esse e outros fins, a tecnologia de imprimir é adotada pelas instituições com o objetivo de estabelecer e fazer cristalizar-se a língua unificada; essa apropriação produz, por tabela, uma divisão dos usuários da língua em dois grupos: letrados/alfabetizados e iletrados/analfabetos. Abre-se, então, o caminho para a formulação de hipóteses sobre uma suposta brecha do letramento, isto é, para um alinhamento ideológico entre escrita (e seus praticantes) e racionalidade, civilização e desenvolvimento científico, por um lado, e entre fala (ou populações não letradas) e irracionalidade, déficit cognitivo e disfuncionalidade social, por outro.

Como explica Maingueneau (1995), as mutações na linguagem escrita, sobretudo de natureza tipográfica, que se observam nesse período, manifestam, na materialidade do texto, as transformações sociais e políticas em curso. A normalização da ortografia reflete e reforça a pretensa homogeneidade da massa de leitores. A pontuação unívoca permite ao leitor recitar para si mesmo e impõe à leitura a primazia da relação com o idêntico e não com o outro. Surge (em parte por influência de limitações da tecnologia de imprimir) o parágrafo como elemento estruturador dos textos, que faz coincidirem a articulação visual da página e a articulação intelectual ou discursiva que virá a tornar-se própria da escrita. Sobretudo, leitura e escrita passam a ser atos de foro privado que permitem registrar pensamentos ou prazeres proibidos, e logo imiscuem-se com as noções de moralidade, privacidade, individualidade e identidade, constituindo-se em fatores chave de uma nova subjetividade.

Do ponto de vista econômico, a possibilidade de reprodução técnica da escrita em larga escala redundou na emergência de um mercado edito- 
rial e, com ele, na possibilidade da compra/consumo de textos pela população, algo impensável na era dos manuscritos reproduzidos e guardados a sete chaves nos monastérios medievais. Assim, em combinação com a forte tendência de normatização da língua, os mecanismos de inclusão/exclusão via linguagem passam também a ser influenciados por fatores de classe social e de valoração econômica. Tal fato acrescenta vulto a uma outra dimensão do acesso na relação entre letramento e inclusão: a capacidade financeira de consumir textos que definiam os temas e difundiam as narrativas centrais para a participação do cidadão na esfera pública.

Concomitantemente à emergência desse mercado da escrita, o desenvolvimento dos diversos mecanismos estatais de imposição e manutenção da disciplina ${ }^{3}$ redunda naquilo que Certeau (1984) chama de aparelhos escriturísticos, i.e. um amplo e pormenorizado sistema de registro e gerenciamento de informações relacionadas à educação, saúde pública, justiça, e demais serviços públicos vistos como estratégicos para a nação. A instituição desse sistema, ainda segundo Certeau (1984: 222; 230), é "indissociável da 'reprodução' possibilitada pela imprensa" e, ao mesmo tempo, "acompanhada pelo duplo isolamento do 'Povo' (em relação à 'burguesia') e da 'voz' (em relação à escrita)”. Fortalecem-se com isso os mecanismos que fazem da escrita "um princípio de hierarquização social que privilegia, ontem o burguês, hoje o tecnocrata”, mas, simultaneamente, a dependência desses aparelhos escriturísticos obriga o Estado a prover mecanismos e canais mínimos de acesso ao letramento, tais como escolas e bibliotecas públicas.

A educação formal - instância privilegiada de massificação do letramento na maior parte dos estados nacionais do Ocidente, mas também de controle e seleção de formas autorizadas ou desejáveis de prática da leitura e da escrita nas sociedades modernas - torna-se uma agência na qual se busca estabilizar e normatizar as relações entre certos tipos de letramento e certas possibilidades de acesso do cidadão a espaços de participação política. Frente às forças centrífugas da cultura popular e das formas locais de apropriação da escrita, a escola adquire, no Estado-nação, um papel essencialmente centrípeto: não apenas massifica a escrita - e conseqüentemente, a língua nacional normatizada, mas também define os tipos de prática

3 Utilizo a palavra "disciplina" no sentido proposto por Foucault (1977), isto é, para me referir às estratégias de controle e domínio da energia produtiva do indivíduo por parte dos poderes constituídos. 
de leitura e escrita que efetivamente contam como capacitação. Assim, a legitimação do sujeito no universo das relações sociais mediadas pela língua e pela tecnologia da escrita torna-se irremediavelmente subordinada à escolarização, que lhe deve preceder. Isto equivale a dizer que, declaradamente, nem todos os que nascem no território são cidadãos desde a partida. A todos é dada apenas, supostamente, a oportunidade de habilitarem-se para a cidadania, através da escola.

As relações entre letramento e inclusão vistas sob o prisma da educação formal, contudo, revelaram-se extremamente dúbias no sentido de que, sob a aparência de um sistema meritocrático capaz de preparar os indivíduos oriundos de diferentes grupos sociais para uma inserção mais vantajosa nas relações legais, de trabalho e de consumo na Nação, a escola foi se tornando, ao longo da história, num mecanismo institucionalizado de exclusão daqueles que nela chegam sem o domínio dos códigos culturais e sem as disposições relativas ao trabalho intelectual que caracterizam as elites. Como já demonstraram Bourdieu e Passeron (1977), a escola, formulada nessas bases, apenas aprofunda e legitima a marginalização das classes populares e/ou grupos culturais periféricos, enquanto privilegia sujeitos que já dispõem dos capitais ${ }^{4}$ lhes assegurarão a manutenção de posições sociais privilegiadas.

Soma-se à problemática da educação formal nesse período o fato de que a escola vai necessariamente incorporando, por força de sua condição institucionalizada, discursos e orientações ideológicas impostas pelo próprio modo de desenvolvimento capitalista-industrial de orientação liberal. Collins e Blot (2003) explicam como isso se deu nos Estados Unidos, caso paradigmático no Ocidente. Os autores mostram que já no final do século XVIII havia na mentalidade das elites norte-americanas uma forte associação entre práticas específicas de letramento e legitimidade do sujeito na esfera pública. A utilização de jornais de prestígio como subsídio para o

\footnotetext{
4 Refiro-me a essas três formas de capital com base em Bourdieu (1986), para quem o termo "capital" designa qualquer recurso ou bem, material ou simbólico, que permita a seu possuidor apropriar-se de lucros decorrentes de sua participação em determinada arena social. Grosso modo, podemos entender por "capital cultural" a familiaridade do indivíduo, adquirida em sua socialização primária, com os códigos culturais, inclusive o lingüístico, e com certas predisposições culturais das classes dominantes. Por "capital social” entende-se uma rede mais ou menos durável de relacionamentos, conhecimento e reconhecimento mútuos de que um indivíduo dispõe e que lhe faculta a obtenção de "crédito", nos vários sentidos da palavra, em sua comunidade.
} 
debate sobre os destinos do país, por exemplo, era vista como uma forma fundamental de participação cívica. Desse debate, entretanto, excluíam-se grupos pouco escolarizados tais como as mulheres e os afrodescendentes, sob o pretexto de que os mesmos não dispunham das capacidades letradas (e ou racionais) necessárias.

Das primeiras escolas públicas abertas às camadas populares - camponeses, imigrantes e operários brancos - denominadas genericamente charity schools, não se esperava que desenvolvessem capacidades racionais ou argumentativas na população, mas apenas que nela inculcassem os hábitos e valores da obediência, da pontualidade, da economia, da higiene pessoal, enfim, da disciplina, sem o quê não se poderia permitir sua inserção, ainda que subalterna, nos modos de vida da elite urbana culta.

Ao longo dos séculos XIX e XX, ao mesmo tempo em que os excluídos tradicionais (mulheres, afrodescendentes, imigrantes) foram incorporados a um sistema escolar, os letramentos praticados na família, na comunidade, na igreja, nos locais de trabalho, etc. foram fortemente deslegitimados. O letramento escolar vai se fortalecendo em torno de um sistema integrado e estandardizado de textos oficialmente aprovados, mensurações, avaliações e ranqueamentos que estabeleciam, desde cedo, uma separação entre sujeitos aptos para a educação humanística nas artes liberais e aqueles fadados à instrução técnica para o emprego na cadeia industrial. Seguiu-se, então, um processo a que Collins e Blot (2003) se referem como corporitização da América, e, com ele, uma grande valorização, no âmbito da escola, dos ideais da eficiência técnica, da descrição quantitativa da realidade e do planejamento racional. Cristaliza-se, com isso, a noção de letramento como capacidade cognitiva mensurável e indispensável à condição de funcionalidade do indivíduo na democracia, noção essa que, nos dias de hoje, vemos muitas vezes estendida diretamente à capacidade de utilizar as TIC, nos discursos do senso comum sobre inclusão digital.

Sumarizando esta seção, o processo político de implantação do Estado-nação e a conseqüente emergência da escola como principal agência de letramento das populações redundaram numa concepção etnocêntrica e disciplinar de letramento, a qual, por sua vez, fez, e continua a fazer, do letramento muito mais um mecanismo de homogeneização, exclusão e submissão do que de inclusão, expressão da diferença e transformação social. Foi apenas a partir de estudos que buscaram investigar as práticas de 
letramento em contextos (culturais e de prática) variados, que, já no final do século XX, autores como Heath (1983), Street (1984) e Scribner e Cole (1981) conseguiram trazer à luz a forte dependência existente entre letramento, cultura e poder, e, dessa forma, abrir caminho para uma reflexão crítica sobre a relação entre letramento e inclusão.

\section{A perspectiva sociocultural}

A perspectiva sociocultural nos estudos de letramento emergiu do diálogo entre diferentes áreas do conhecimento, tais como a Lingüística, a Antropologia, a Sociologia, a Análise Conversacional, a Etnografia da Fala, a Psicologia Social, etc. Na prática, e traduziu-se em diversas correntes ou movimentos de pesquisa que buscaram reagir à tendência cognitivista que tomara conta das discussões relacionadas ao letramento e à escolarização nas décadas anteriores, e, com isso, inseriu-se na guinada social mais ampla pela qual passaram as Ciências Humanas no terceiro quarto do século XX (cf. Gee, 2000).

Boa parte da produção acadêmica daí resultante identifica-se com os assim chamados Novos Estudos sobre o Letramento, uma vertente de pesquisa que se desenvolveu a partir dos trabalhos seminais de Heath (1983) e Street (1984). Segundo Street (2003: 1), os Novos Estudos sobre o Letramento representam uma tradição questionadora das abordagens dominantes do letramento, no sentido de problematizam "o que conta como letramento em cada lugar ou tempo específicos e questionam 'de quem são' os letramentos dominantes e 'de quem são' os marginalizados ou os que resistem”.

Dois marcos conceituais desses estudos são as distinções entre modelo autônomo e modelo ideológico do letramento (Street 1984), e entre evento de letramento e prática de letramento (Heath 1983; Street 1988). A primeira distinção questiona a crença anterior de que a alfabetização da população, como variável autônoma, teria efeitos previsíveis sobre o seu desenvolvimento cognitivo ou sociocultural. Ocorre que, "na prática", como explica Street (2003: 1), "o letramento varia de contexto a contexto e de cultura a cultura e, portanto, também variam os efeitos de diferentes letramentos em diferentes condições". Já a distinção entre eventos e práticas de letramento, remete à necessidade de considerarem-se as maneiras como se pratica a escrita (e a leitura) em situações específicas, além dos padrões de 
atividade que giram ao redor desses eventos. Uma das conseqüências mais importantes do enfoque nos eventos de letramento é que ele elimina a dicotomia entre oralidade e escrita - até então tomada como pressuposto e demonstra existir nas práticas interpretativas da escrita um entremeamento de códigos, registros e modalidades lingüísticas e semióticas, de modo que os sentidos são sempre negociados e construídos interativamente.

As maneiras pelas quais essas combinações se dão e esses sentidos são construídos tendem a ser aprendidos desde cedo no seio das comunidades, e podem variar enormemente em função o grupo e/ou finalidades envolvidos. Heath (1983) mostrou que a imposição de um desses padrões culturais de interação com o texto (o da classe média branca anglo-saxônica) na escola, como se fosse neutro, levava, em última instância, a que educadores e pesquisadores imputassem indevidamente déficits cognitivos e lingüísticos aos indivíduos oriundos dos grupos étnicos/culturais marginalizados. Basta-nos esse exemplo para afirmar, com relação ao letramento digital, que os processos de inclusão e exclusão via letramento precisam levar em conta muito mais dimensões do que as do acesso e da capacitação.

É plausível supor que a perspectiva sociocultural dos estudos de letramento seja útil para a pesquisa em inclusão digital, mas, para tanto, devemos considerar um cenário em que (i) o projeto político do Estado-nação está abalado, e (ii) novas tecnologias diversificam e complexificam continuamente as práticas de linguagem, os perfis dos sujeitos letrados e as ideologias sobre o papel da leitura e a escrita. Também será preciso voltar nossas lentes críticas para os estudos dessa vertente no sentido de admitir que não apenas há letramentos diferentes em diferentes contextos, mas também que cada letramento e cada contexto é fundamentalmente heterogêneo, mutável e conectado a outros (i.e. dialógico). Na seção seguinte, retomo a perspectiva histórica da relação entre inclusão e letramento, tendo em vista a necessidade de fundamentar essa visão crítica.

\section{Desdobramentos do mundo pós-nacional}

Vive-se hoje, ao menos em alguns tempos-espaços do mundo, um momento descrito como pós- (industrial, nacional, materialista, moderno, etc.), mas que, por assim dizer, ainda não esgotou aquilo de que diz-se ser posterior (Giddens 1991). Sobretudo a fórmula política do Estado-nação 
tem sido ameaçada por processos acelerados de interpenetração econômica, cultural e tecnológica entre os países, num processo ao qual vários autores se referem como globalização. Paradoxalmente, porém, a globalização tem reacendido o ideal do Estado-nação como horizonte para muitas das ações e reivindicações políticas da atualidade, assim como tem feito renascerem formas pré-modernas de identificação e pertencimento, tais como a etnia e a religião (Hall, 2005). Sobretudo, o Estado-nação permanece como única instância jurídica supostamente garantidora da cidadania para populações que cada vez mais se mobilizam, legal ou ilegalmente, entre países ou entre "territórios culturais" dentro de um mesmo país, em busca de trabalho, refúgio ou liberdade.

Essa nova perspectiva da relação entre território, identidade e cidadania afeta a formulação tradicional de inclusão nas sociedades democráticas de duas maneiras importantes. Por um lado, ocorre um "afrouxamento de fortes identificações com a cultura nacional, e um reforço de outros laços e lealdades culturais, acima e abaixo do nível do Estado-nação" (Hall 2005:73); por outro, "torna-se problemática a figura do cidadão como membro de uma comunidade nacional limitada” e coloca-se frente aos estados nacionais o desafio de "reconfigurar o indivíduo político em relação a condições de globalização" (Poster 2004:321).

Para os mais críticos, o que está em curso é simplesmente uma nova onda de homogeneização cultural (ou a atuação de forças centrípetas mais poderosas e articuladas em rede). Essa onda, entretanto, não se realiza mais, como no passado, pela imposição/construção de comunidades imaginadas (Anderson 1983) por meio das quais se estabelecem laços de lealdade com o Estado, mas sim pela emergência de "identidades partilhadas' - como 'consumidores' para os mesmos bens, 'clientes' para os mesmos serviços, 'públicos' para as mesmas mensagens e imagens - entre pessoas que estão muito distantes umas das outras no espaço e no tempo" (Hall 2005: 74). Diz-se, então, que a globalização, nesse sentido, é melhor descrita como uma onda de americanização ou ocidentalização do mundo via consumo, razão pela qual muitos se referem a ela como MacDonaldização do mundo. Note-se, porém, que esse processo se aproxima e se distingue, ao mesmo tempo, daquele promovido pelo Estado-nação, trazendo conseqüências para as políticas lingüísticas e educacionais da modernidade. Isto porque, agora, "as diferenças e as distinções culturais, que até então definiam a identidade, ficam reduzidas a uma espécie de língua franca internacional 
ou de moeda global, em termos das quais todas as tradições específicas e todas as diferentes identidades podem ser traduzidas" (Hall 2005:76).

Há que se considerar, contudo, que ao conectarem (ou possibilitarem a ação à distância entre) formações socioculturais remotas, as TIC não apenas apóiam a MacDonaldização do mundo, mas também viabilizam novas formas de conexão entre os diferentes/resistentes/discordantes. Esses, por sua vez, passam a reivindicar, agindo em rede, o direito de serem, ou voltarem a ser, étnicos, orgânicos, analógicos, situados, etc. É a linguagem das TIC, em última instância, que fornece a gramática através da qual as diferentes identidades e tradições culturais vão sendo codificadas de modo a poderem ser consumidas globalmente (Castells 1999). Mas, são também as novas conexões viabilizadas pelas TIC, que se contrapõem à guetização e à cristalização dos contextos, e que, portanto, abrem novas possibilidades de fertilização cruzada e ação convergente entre línguas, práticas e identidades distintas.

$\mathrm{Na}$ ausência de mecanismos políticos supranacionais capazes de promovê-la efetivamente (Poster 2004), a cidadania permanece uma noção dependente da fórmula política do Estado-nação. Porém, ganha força, sobretudo nas ex-potências coloniais, que agora recebem um fluxo incessante de imigrantes das ex-colônias, uma nova concepção de inclusão "com sensibilidade para as diferenças". Ou dito nos termos de Habermas (2002), começa a acontecer, no ocidente liberal, seja por vontade política, seja por força das circunstâncias, um desacoplamento entre cidadania e homogeneidade cultural. É também Habermas (2002: 172) quem nos dá o mote para a centralidade das práticas de linguagem nesse processo, quando adverte que esse movimento de inclusão "não deve dilacerar a sociedade numa miríade de subculturas que se enclausuram mutuamente". Adverte o autor, ainda, que se por um lado, "a cultura majoritária deve se soltar de sua fusão com a cultura política geral (...), caso contrário, ela ditará a priori os parâmetros dos discursos de auto-entendimento", por outro, "as forças de coesão da cultura política comum (...) devem continuar a ser suficientemente fortes para que a nação dos cidadãos não se despedace".

Isso equivale a admitir que a inclusão, hoje, é um processo tenso, simultaneamente centrípeto e centrífugo, que se coaduna com a concepção dialógica da linguagem. Essa visão nos sugere que tal tensão não se aliviará através de mecanismos de aculturação e assujeitamento, nem, tampouco, é 
razoável esperar que se alivie de qualquer forma. O que se tenta pensar como inclusão é, efetivamente, o estabelecimento de uma ética (e uma ação política a ela subordinada) capaz de afirmar a distinção entre desigualdade (a combater) e diferença (a proteger), assim como entre igualdade (a construir) e homogeneização (a prevenir).

\section{Inclusão e transculturalidade}

O processo de reformulação das formas de ser sujeito e cidadão em virtude dos processos simultâneos de aumento da complexidade interna e de ampliação das conexões externas nas sociedades contemporâneas tem sido teorizado em certos círculos por meio do conceito de transculturalidade (Welsch 1999; Kostogriz 2004; Epstein 2005). Em nível macrossocial, a transculturalidade pode ser identificada como o emaranhamento e/ou a interdependência entre culturas e formas de vida num mesmo território e/ ou espaço de comunicação simbólica, que redunda em formações culturais híbridas; ou, de forma mais incisiva, põe à mostra a heterogeneidade constitutiva de todas as culturas que processos políticos anteriores buscaram apagar. No nível dos indivíduos, o conceito de transculturalidade enfatiza as múltiplas conexões culturais (não apenas em termos étnicos, lingüísticos ou de origem nacional, mas também de gênero, classe, faixa etária, etc.) que caracterizam os sujeitos contemporâneos, assim como o fato de que esses sujeitos transitam quotidianamente numa rede de relações a partir da qual componentes identitários vão ganhando (e perdendo) sentido e relevância interativamente.

Alguns autores começam a apontar que essas mutações na identidade, na cidadania e no ideal da inclusão afetam também dois pilares das teorias de letramento de cunho sociocultural. Primeiro, a noção de sujeito situado, enraizado num mesmo lugar e/ou num espaço cultural homogêneo, no qual florescem laços de solidariedade e visões de mundo compartilhadas começa a ser relativizada (Kleiman e Vieira 2006). Segundo, o pressuposto de que o contexto cultural é algo delimitável territorialmente, e que préexiste às próprias práticas de linguagem tem sido revisto (Gee 2000).

Some-se a isso a constatação de que o embate discursivo entre as forças da diferença e da padronização se faz num meio tecnológico que (i) é também híbrido (no sentidos de Manovich 2001 e Buzato 2007a), (ii) ain- 
da está longe de estabilizar-se ou de esgotar seu potencial de inovação, e (iii) estabelece conexões em direções e velocidades que simplesmente não podem ser controladas totalmente (embora possam ser vigiadas e reprimidas). Ademais, o mundo vai se tornando cada vez menos um conjunto de territórios (geográficos ou imaginários) unificados e limitados, e cada vez mais uma enorme faixa de fronteira, um lugar onde liberdade e repressão se encontram face a face, e onde inclusão e exclusão não são sinais opostos, mas movimentos simultâneos, quotidianos, naturais.

Não pretendo, obviamente, afirmar que estamos vivendo uma ruptura com as formas tradicionalmente estabelecidas de articulação entre linguagem, tecnologia, identidade e cidadania sob o impacto autônomo das TIC, dado que as relações de poder estabelecidas ao longo da história do Estado-nação também se renovam e se descentralizam por meio dessas tecnologias. Mas é possível afirmar que, se tais elementos se articulam no momento de maneiras mais complexas, e ainda mais contraditórias, também nossa concepção de letramento precisa ser repensada a partir de noções de conexão, trânsito e fronteira. É nesse sentido que proponho, a seguir, uma problematização do conceito de letramento(s) digital(is) ${ }^{5}$.

\section{Letramento(s) Digital(is): problematizando o conceito}

Soares (2002: 151, itálicos no original) define letramento digital como

um certo estado ou condição que adquirem os que se apropriam da nova tecnologia digital e exercem práticas de leitura e de escrita na tela, diferente do estado ou condição - do letramento - dos que exercem práticas de leitura e de escrita no papel.

Tal definição abre caminho para uma linha de investigação que procura identificar de que forma

as práticas de leitura e de escrita digitais, o letramento na Cibercultura, conduzem a um estado ou condição diferente daquele a que conduzem as práticas de leitura e de escrita quirográficas e tipográficas, o letramento na cultura do papel.

5 Pode-se postular, como farei mais adiante, que assim como no caso do letramento dito tradicional, há letramentos digitais diferentes praticados para finalidades diferentes em contextos diferentes. Por essa razão, a partir deste ponto, sigla LD referir-se-á tanto à expressão letramento digital, no singular, quanto ao seu plural, letramentos digitais, a depender do contexto frasal em que aparece. 
Essa maneira de conceituar e abordar o LD é congruente com a que têm utilizado diversos outros autores (Bolter 1993; Snyder 1997; Kress 2005) preocupados em explicitar as diferenças e os processos de transição entre os letramentos tradicional e digital, e em avaliar suas repercussões, em especial nos contextos educacionais. Em geral, estudos dessa vertente focalizam os mesmos dois aspectos em que está centrada a análise de Soares (2002): a mudança no espaço de escrita, da página para a tela, e os novos mecanismos de produção, reprodução e difusão dos textos eletrônicos, nomeados genericamente como hipertextos ${ }^{6}$.

De forma bem sucinta, pode-se dizer que, do ponto de vista do espaço da escrita, os estudos têm buscado caracterizar os LD pelo viés da utilização de telas eletrônicas sobre as quais o texto e/ou imagens aparecem organizado(s) na forma de janelas que se aninham ou se sobrepõem espacialmente, ou se sucedem temporalmente. Este novo suporte ${ }^{7}$, ou superfície da escrita, é tido como fortemente relacionado não apenas à grande flexibilidade e multilinearidade na progressão da leitura e da escrita, como também a uma utilização muito mais intensa de imagens ${ }^{8}$, sob suas diversas formas (ícones, imagens fotorealistas, vídeos digitais, animações vetoriais, emoticons, etc), e com funções variadas (não apenas ilustração, mas também navegação, organização, referenciação, etc.), nos textos digitais. Apoiados nessas análises, muitos outros estudos têm buscado descrever e

\footnotetext{
6 O conceito de hipertexto não apenas é heterogêneo nos estudos lingüísticos (nos quais é teorizado tanto como meio quanto como gênero ou tipo textual), como também presta-se a enfoques semióticos, sociológicos, filosóficos, cognitivos e pedagógicos, entre outros (ver Komesu 2005). Assim, o que faço aqui é uma reconhecida e lamentável redução, necessária, porém, em vista da falta de espaço e da complexidade já existente na questão mais central do artigo, que é a da relação entre letramento e inclusão (digital).

7 A utilização do termo "suporte" para fazer referência às telas eletrônicas é tão freqüente na literatura quanto problemático. É problemático no sentido de que a tela é apenas um dispositivo através do qual se pode ter acesso a textos (escritos ou de outra natureza) que estão codificados em outra linguagem (elétrica/binária) em suportes propriamente ditos (isto é, discos magnéticos, tabletes de silício, etc.) não legíveis por seres humanos.

8 Embora essa proliferação da imagem repercuta em praticamente todos os textos contemporâneos, e não apenas os eletrônicos, convém notar que barreiras, tais como o custo elevado reprodução de imagens coloridas e a dificuldade de acesso a repositórios de imagens de boa qualidade gráfica por parte do leitor/escritor comum, têm sido grandemente amenizadas pelas TIC. Basta citar como exemplo os milhões de telefones celulares com câmaras digitais que agora circulam nas mãos de boa parte dos 90 milhões de brasileiros "conectados" a esses serviços, e que podem ser quase que instantaneamente compartilhadas e difundidas por meio de redes comunitárias locais (via tecnologia de blue tooth) e outras redes, via websites como o YouTube.
} 
avaliar as diferentes aplicações e implicações da textualidade digital em diferentes âmbitos como, por exemplo, no da produção de materiais didáticos (Braga 2004), no da comunicação jornalística (Palácios e Mielniczuk 2002.), e no da formação de leitores críticos (Lemke 1998, Buzato 2007b).

Do ponto de vista dos mecanismos de produção, difusão e reprodução dos textos digitais, os autores simpáticos à tese da ruptura entre o digital e o tradicional têm destacado o fato de que os textos eletrônicos multilineares, ou hipertextos, produzidos, estocados e lidos em computadores e/ou redes telemáticas espacialmente distribuídas, enfraquecem o princípio da autoria, i.e., que facultam ao leitor um papel mais ativo na construção dos percursos de leitura, e, portanto, um maior grau de abertura para a construção de suas interpretações. Além disso, o fato de muitos desses textos estarem abertos à construção coletiva também é visto como um fator de fragilização do limite, mais facilmente imposto nos textos impressos, entre autor e leitor, ou entre leitura e escritura (Landow 1997).

A combinação dessas mudanças, tanto na superfície da escrita, quanto nos mecanismos de produção, reprodução e difusão dos textos, é, não raro, vista como tendo importantes repercussões cognitivas e epistemológicas. Atribui-se aos textos digitais as capacidades de reificarem o conceito de intertextualidade e de desfavorecerem os discursos monológicos típicos do livro impresso (Lemke 1998), destacando-se como característica importante dessa nova textualidade a impossibilidade de localizar-se um centro privilegiado de significação. Esses dois fatores, entre outros, têm sido apontados como geradores de uma nova relação da humanidade com o conhecimento, visto agora mais claramente como algo essencialmente transitório, contextual e construído coletivamente (Lévy 1999).

Sem questionar o mérito dessas abordagens, penso que falta, ainda, para a construção de uma perspectiva sociocultural do LD que possa efetivamente nortear a pesquisa em inclusão digital, levar em conta alguns problemas. Em primeiro lugar, é necessário encontrar mecanismos de análise que, em lugar de enfatizarem, ou de refutarem, descontinuidades entre os letramentos (tradicional e digital), desnudem os modos da sua convergência e da sua hibridização. Penso que um passo importante nesse sentido seria dar-se menos ênfase ao meio ou superfície da escrita, a partir da constatação de que, por serem praticados ou discursados, os meios materiais nos quais se fixam (ainda que temporariamente) sistemas de representa- 
ção, como a escrita, não têm necessariamente a força determinante que muitos estudos lhes atribuem ${ }^{9}$. Não se trata, contudo, de postular um continuum entre tradicional/digital, pois que tal formulação nos apresentaria a necessidade de sustentar, ainda que prototipicamente, a existência de pólos - impresso e digital - homogêneos.

Em segundo lugar, as pesquisas muitas vezes objetivam descrever impactos ou efeitos dos LD sobre as comunidades, instituições e/ou indivíduos em detrimento do movimento em sentido contrário, isto é, das formas como diferentes grupos se apropriam desses letramentos e lhes conferem significados, finalidades e valores diversos, ou para utilizar um enfoque bakhtiniano, lhes impregnam com seu próprio horizonte apreciativo, em uma dada situação sócio-histórica única.

Em terceiro lugar, é preciso enfatizar que os novos mecanismos de produção, reprodução e difusão dos textos eletrônicos são fatores-chave não apenas para o estabelecimento de uma nova relação com o conhecimento, mas também para a ampliação da transculturalidade. Pode-se, mesmo, argumentar que as novas possibilidades de conexão entre sujeitos remotos engendradas pelas TIC estão produzindo uma mutação na noção tradicional de contexto (Buzato 2007c), com a qual uma perspectiva sociocultural do LD precisa lidar ${ }^{10}$.

A estes fatores somam-se ainda dois outros que, se não especificamente ligados ao LD, ganham com ele forte relevância. Um diz respeito à noção ampliada de letramento como prática social, que envolve outros códigos e tecnologias além da escrita alfabética (Barton 1994). Creio que, no caso do $\mathrm{LD}$, essa noção ganha especial relevância em razão da rápida convergência de todas as mídias, e, portanto, de quase todas as mensagens e sistemas de representação, para uma mesma matriz digital e interligada de produção e circulação (Castells 1999). O outro fator diz respeito à necessária articulação entre LD e letramento crítico, essencial para qualquer

\footnotetext{
9 Agradeço a Roxane Rojo por chamar minha atenção para o problema da nomenclatura (suporte/ superfície), e empresto dela, via comunicação pessoal, essa argumentação contra a ênfase excessiva nas propriedades dos suportes em detrimento das maneiras como são praticados/discursados.

10 Não há espaço para aprofundar essa questão aqui, mas basta dizer que as possibilidades de interação simultânea com diversos interlocutores, on-line e off-line, em tempo real perturbam consideravelmente a noção de contexto como um contêiner pré-existente às práticas de linguagem que nele se realizam (ver, por exemplo, Leander e McKim 2003).
} 
teoria de inclusão que se pretenda coerente com a idéia de transformação dos sujeitos e das relações de poder.

O desejo de articular todos esses pressupostos por meio do conceito de LD esbarra, entretanto, nas taxonomias já consagradas na literatura, as quais, em geral, classificam o LD como um subtipo de letramento (seja este visto como prática social, capacidade pessoal, ou como estado/condição do indivíduo), cuja especificidade residiria em ser o computador/a tela eletrônica o meio tecnológico/suporte de que depende (Papert 1980 e Selfe 1999, por exemplo).

Ocorre que essa mesma literatura permite que se estabeleçam conexões importantes entre LD e outros letramentos, não necessariamente subordinados ao critério da superfície da escrita, ou dos meios de produção, difusão e recepção do texto. Me refiro, por exemplo, a categorias tais como letramento de mídia [media literacy] (Silverblatt 1995), letramento numérico [numeracy] (Lemke 1998) e letramento visual [visual literacy] (Bolter 1998). Além disso, as pesquisas em LD também fazem referência a categorias de letramento baseadas no propósito, disposição ou atitude diante do texto, tais como letramento de informação [information literacy] (Glister 1997), e letramento crítico [critical literacy] (Lankshear e Knobel 1998).

A incidência dessas diversas categorias sobre um mesmo conjunto de práticas, tecnologias e sujeitos não se resolve, na verdade, com a ajuda de uma categoria superordenada, como atesta a emergência, em anos recentes, do conceito de multiletramentos [multiliteracies]. Cunhado por um grupo de pesquisadores anglófonos que se autodenominou New London Group (1996), o termo multiletramentos refere-se às estratégias pedagógicas vistas como necessárias para dar-se conta do aumento da complexidade dos textos (impressos, digitais ou de outra natureza) que circulam nas sociedades contemporâneas. Tal complexidade, para aqueles autores, resulta de dois fatores básicos: a proliferação de textos multimodais, com o concomitante declínio do modelo tradicional de texto escrito; e a maior saliência dos fatores culturais envolvidos na produção e interpretação de textos, ocasionada pela transculturalidade crescente no mundo.

Poder-se-ia, com base nesses autores, pensar nos LD também como multiletramentos, nesse caso multiletramentos que têm em comum o fato de dependerem da mediação digital. Mas isso, de fato, nem resolveria o problema da pouca consistência do par opositivo digital/impresso a que já 
me referi, nem faria jus ao hibridismo que caracteriza os letramentos digitais, isto é, ao fato de que a convivência entre tais múltiplos resulta em entrelaçamentos, ambigüidades, conflitos e refuncionalizações entre as práticas e os repertórios de habilidades dos sujeitos. Dito de outra forma, vejo os letramentos digitais menos como multi-, e mais como inter- ou trans-. São indícios desse hibridismo, por exemplo: a ambigüidade entre fala e escrita que caracteriza interações síncronas via Internet, a mistura de convenções da escrita acadêmica com estratégias de envolvimento e marcas de informalidade em listas de e-mail acadêmicas, o uso de recursos da gramática do cinema (cortes, câmara subjetiva, panorâmicas e close-ups) nas interfaces gráfico-textuais dos dispositivos digitais (Manovich 2001), a existência de palavras na tela que o computador trata, internamente, como se fossem imagens e vice-versa (Buzato 2007a), a necessidade/capacidade de avaliar criticamente os resultados oferecidos por um site de buscas em resposta a determinadas palavras-chave, e assim por diante.

Nesse sentido, o melhor critério de especificidade para os LD que se nos apresenta talvez seja justamente sua propriedade de deixar ou fazer hibridizarem-se os seguintes elementos constitutivos de quaisquer letramentos: (i) formas de mediação (tais como a imprensa, o vídeo, a fotografia, o rádio, o cinema, etc.), (ii) sistemas de representação (tais como a escrita alfanumérica, as diversas linguagens imagéticas, os diversos tipos de cartografia e infografia, a música, etc.), (iii) gêneros, oriundos de diferentes esferas de atividade social e diferentes tradições culturais que se conectam via TIC, (iv) atitudes ou disposições frente ao texto (ler para procurar informação, ler para criticar, ler para se divertir, etc.), compartilhadas em eventos coletivos de LD e (v) letramentos diversos praticados por um mesmo sujeito que transita entre contextos culturais e de prática diferentes.

Pensar o LD dessa forma não significa simplesmente contornar um problema taxonômico que se nos apresenta na literatura. Significa adotar, em seu lugar, mesmo que transitoriamente, uma concepção relacional de letramento e, ao mesmo tempo, uma ferramenta heurística para descrever os LD: a noção de rede. É, na verdade, uma forma de não sucumbir à necessidade de categorizar o que ainda está em plena emergência, mas, ao mesmo tempo, de chamar as categorias/perspectivas já estabelecidas ao diálogo e à interpenetração.

Os letramentos digitais seriam, então, não apenas, ou necessariamente, aqueles situados num contexto cultural/institucional/midiático parti- 
cular, mas configurações específicas desses letramentos em rede acionadas em situações, para finalidades e/ou por sujeitos e comunidades de prática específicos. Assim, também, ao reconhecer como característica central dos LD o fato de que eles conectam sujeitos remotos em tempo real ou atrasado, estaríamos abrindo uma linha de pesquisa para a caracterização desses letramentos como construtores de contextos transculturais, ou como objetos fronteiriços (Wenger 1998, Buzato 2008), que estabelecem zonas de contato entre nós e o outro.

A partir desses pressupostos, e tendo como pano de fundo a problemática da inclusão, proponho uma concepção alternativa de letramentos digitais, não mais como tipos de letramento contrapostos aos tradicionais, mas como redes complexas e heterogêneas que conectam letramentos (práticas sociais), textos, sujeitos, meios e habilidades que se agenciam, entrelaçam, contestam e modificam mútua e continuamente, por meio, virtude ou influência das TIC. Ao mesmo tempo em que os especifica, essa maneira de conceituar os letramentos digitais busca não dicotomizar sua relação com os letramentos ditos tradicionais, que continuam a ser significativos em praticamente todos os contextos de prática. Além disso, põe em primeiro plano da análise o fato de que os LD são inevitavelmente instáveis.

Resta explicar, ainda, de que forma tal definição responderia à necessidade, fundamental para que se pense em inclusão como algo além da adaptação da população a demandas dos poderosos, de articularmos LD e letramento crítico. Nesse sentido, dois conceitos importantes encontrados na obra de Bakhtin $(1988,2003)$ podem ser operativos: exotopia e híbrido intencional.

Pode-se definir exotopia como um princípio filosófico, ligado à concepção dialógica da linguagem, segundo o qual cada um de nós só pode ver-se de maneira acabada por meio do olhar do outro. Dito de outra forma, cada sujeito/cultura/comunidade só pode ter de si uma consciência parcial; dispõe, por assim dizer, de um horizonte aberto ao seu redor, até que, no diálogo com o outro, encontre seu limite, seu acabamento provisório (assim como cada enunciado só receberá seu acabamento por meio de uma réplica). Por nos ser externo, o outro tem um excedente de visão sobre nós, assim como nós sobre ele. Daí que nós somente conseguimos nos ver completamente como sujeitos, na relação, necessariamente dialógica, que estebelecemos com os outros. 
Com relação ao conceito de híbrido intencional (ou semântico), tratase, para Bakhtin (1988), de um enunciado produzido por um artífice/estilista - como um autor literário, por exemplo - no qual duas linguagens/ consciências estão justapostas. Por conta dessa justaposição, estabelece-se um conflito, um processo agonístico, através do qual as diferenças entre as linguagens/consciências iluminam-se umas às outras, de modo que os sentidos permaneçam abertos. Considere-se, então, que os enunciados digitais são sempre híbridos, primeiro porque sempre constituídos de duas linguagens/consciências, uma técnica/do programador, outra cultural/do usuário (Manovich 2001, Buzato 2007a); depois, porque sempre simultaneamente disponíveis ou recuperáveis em múltiplos tempos-espaços.

Pensar os letramentos digitais como letramentos em rede é pensar em exotopia, i.e. é justamente admitir que o sentido de cada letramento não pode ser definido senão no diálogo com outros letramentos, na conexão entre diferentes tempos-espaços, que se dá de forma cada vez mais intensa e variada hoje, em virtude da convergência entre os meios e da proliferação das conexões.Ademais, pensar os letramentos digitais como letramentos em rede é pensar em hibridização, é postular que guardem consigo a possibilidade de abertura de certos sentidos instalados nas ideologias do Local, assim como de resistência ao fechamento de sentidos que acompanha a onda homogeneizante do Global.

Do ponto de vista dos sujeitos, pode-se alegar que, por conta do seu caráter exotópico e híbrido, os enunciados (e os letramentos) digitais lhes facultam ocupar posições fronteiriças, partilhar identidades e gêneros híbridos, cambiantes, e que isso lhes confere a possibilidade de romper com sentidos tradicionais e/ou fechados ${ }^{11}$. Daí a postulação de que os letramentos digitais serão tanto mais potencialmente críticos, quanto mais transculturais.

Concluindo esta seção, vale lembrar que o potencial desses letramentos para a formação de cidadãos críticos não se manifestará, obviamente, apenas pelo contato dos sujeitos com o texto ou o meio. Como no caso dos letramentos ditos tradicionais, a criticidade estará sempre na forma como

\footnotetext{
11 Agradeço a Cristine Gorski Severo por sua contribuição, via comunicação pessoal, na formulação dessa relação entre letramento crítico, letramentos digitais, sujeito e sentido, por intermédio dos conceitos de híbrido intencional e exotopia.
} 
o texto é interpelado, e o meio praticado. Logo, entre o potencial desestabilizante dos sentidos, que os LD ostentam, e a formação efetiva de cidadãos críticos e abertos ao diálogo, se interpõem as concepções de inclusão digital e letramento digital que nortearão a ação das diversas agências, assim como dos atores, envolvidos na inclusão digital. É disso que trata a seção final deste trabalho.

\section{Concepções de inclusão digital e o papel dos LD}

O que apresento a seguir é um esboço de três, dentre as muitas possíveis, concepções de inclusão digital identificadas em Buzato (2007a), a partir de pesquisas bibliográficas, de um estudo de campo realizado em um telecentro na periferia de uma cidade industrial na região metropolitana de São Paulo, e de comunicações pessoais estabelecidas com lideranças e participantes de projetos de inclusão digital no estado de São Paulo. Como já dito, trata-se de um esboço, que cumpre, neste trabalho, meramente a finalidade de ilustrar a utilidade da concepção de letramento digital proposta. Nesse sentido, optei por apresentar ao leitor três vinhetas que, se não servem de prova cabal da existência e/ou abrangência dessas concepções, ao menos constituem índices de que há concepções de inclusão e letramento bastante distintas a nortear a massificação do acesso às TIC no país. Enquanto índices, sua principal serventia é fornecer pistas ao leitor interessado em investigá-las mais profunda e detidamente.

\section{Vinheta 1}

A Microsoft, empresa fabricante do sistema operacional Windows, um software proprietário ${ }^{12}$ utilizado por aproximadamente $86 \%$ dos computadores conectados à Internet em todo o mundo ${ }^{13}$, mantém diversas ações de inclusão digital no país. Entre elas, a iniciativa chamada "Parceiros na Aprendizagem da Microsoft", através da qual a empresa fornece a escolas públicas formas de apoio que "possibilitam desde licenças mais acessíveis

\footnotetext{
12 Software proprietário é todo software cuja cópia, redistribuição ou modificação são em alguma medida proibidas pelo seu criador ou distribuidor, ou permitidas apenas por intermédio de acordos legais que incluem, quase sempre, o pagamento de royalties e cláusulas de confidencialidade quanto ao funcionamento do código fonte.

13 Fonte: Globalstats, disponível em http://www.w3 counter.com/globalstats.php, acesso em 05/ $06 / 2008$.
} 
para uso dos softwares Microsoft em instituições de ensino, até o desenvolvimento de projetos inovadores que necessitam de apoio pedagógico", objetivando "melhorar a qualidade da educação e ampliar a inclusão digital e social por meio dos recursos da tecnologia" 14 .

O sentido dado pela empresa à expressão inclusão digital está explicitado no excerto 1 (com ênfases adicionadas por mim), nos termos de uma comparação entre dois cenários possíveis para o Brasil ${ }^{15}$.

Excerto 1

O sentido da inclusão digital

Imagine dois cenários para o futuro do Brasil:

\section{Cenário 1}

Redução da diferença educacional e social, com a nova geração tendo maior consciência dos problemas e atuando na melhoria da qualidade de vida.

\section{Cenário 2}

Ampliação do abismo educacional e social, com aumento do contingente de pessoas sem condições para disputar postos de trabalho.

A diferença entre a melhor e a pior situação pode estar em uma expressão muito falada, mas pouco praticada: inclusão digital e social.

O envolvimento da Microsoft com iniciativas em inclusão digital relacionadas à educação inclui também um "projeto didático de alfabetização em informática" ${ }^{16}$ denominado Microsoft digital literacy. Na página eletrônica dessa iniciativa, a empresa explica ao leitor que seu o objetivo é "ensinar e avaliar seus conhecimentos e aptidões básicas de computação para que você possa utilizar a tecnologia do computador em seu dia-a-dia e conquistar novas oportunidades sociais e econômicas, tanto no plano pessoal, como no âmbito familiar e comunitário".

14 http://www.microsoft.com/brasil/educacao/parceiro/parcerias.mspx, acesso em 05/06/2008.

15 http://www.microsoft.com/brasil/educacao/parceiro/beth_edicao.mspx, acesso em 05/06/2008.

16 http://www.microsoft.com/about/corporatecitizenship/citizenship/giving/programs/up/digitalliteracy/brz/default.mspx, acesso em 05/06/2008. Note-se o contraste entre o nome do projeto e o termo "alfabetização em informática", para recuperar-se a relevância da discussão oferecida na seção introdutória desse trabalho. 
No excerto 2, destaco (com ênfases adicionadas por mim) o conteúdo de um dos módulos didáticos disponíveis para download no site do projeto.

\section{Excerto 2}

\section{Tópicos do curso Segurança e privacidade do computador}

Lição 1: Visão geral sobre segurança e privacidade do computador Objetivos

1.1. Explicar o que significam os termos segurança e privacidade no que se refere a computadores.

1.2. Identificar as diferentes ameaças hoje existentes no universo da computação e explicar as respectivas soluções.

Lição 2: A proteção do computador e de seus dados

Objetivos

2.1. Identificar vários métodos para proteger o sistema operacional, o software e os dados do computador.

2.2. Identificar as diferentes maneiras de proteção das transações pela Internet e em redes.

2.3. Identificar as medidas de proteção mais usadas nas transações via e-mail ou mensagens instantâneas.

Lição 3: Proteção contra ameaças de segurança para você e sua família Objetivos

3.1. Identificar as medidas mais usadas na proteção da privacidade.

3.2. Descrever como agem os predadores on-line.

3.3. Identificar as principais orientações para proteger as crianças dos predadores on-line.

Lição 4: Como manter seu computador seguro e atualizado

Objetivos

4.1. Explicar a finalidade das diferentes configurações de segurança do computador.

4.2. Identificar as opções disponíveis para manter o computador atualizado.

Lição 5: Ética na informática

Objetivos

5.1. Explicar o que significa o termo propriedade intelectual no que se refere à computação.

5.2 Identificar as diversas legislações de violação de direitos autorais e suas medidas preventivas.

5.3. Identificar as diversas questões jurídicas inerentes à troca de informações. 
Completa essa vinheta a figura 1, cópia de tela da mensagem exibida ao leitor que tenta obter acesso ao conteúdo do módulo didático mencionado no excerto 2, utilizando um programa de navegação não fabricado pela Microsoft ${ }^{17}$ :

Os erros a seguir foram detectados e precisam ser corrigidos antes de usar este programa

1 Neste computador não há uma versão atual do Microsoft Internet Explorer instalada. Se você não instalar o Microsoft Internet Explorer 6 SP1 ou posterior, talvez o visualizador não funcione corretamente. Para obter mais informaçōes sobre o Internet Explorer, visite http://www. microsoft.com/windows/ie. Se vocé estiver instalando este produto de um servidor de rede, entre em contato com o administrador do sistema.

Microsoft|Learning

Figura 1: Mensagem mostrada ao usuário de um programa de navegação alternativo ao da empresa Microsoft que tenta obter conteúdos do Microsoft digital literacy.

\section{Comentário:}

Destaca-se aqui a sutileza discursiva pela qual os elaboradores do website substituíram, nessa mensagem, a idéia de escolha ou opção do usuário/leitor por certo programa de navegação não-Microsoft (perfeitamente funcional no caso de websites comuns) pela de "erro", que necessita ser corrigido. Nota-se ainda que, no excerto 2, o conceito de "propriedade intelectual" aparece subordinado tematicamente ao de "segurança" do usuário (e não da empresa), e que no excerto 1, "uma maior consciência dos problemas" parece fazer parte de um cenário em que não se questiona o porquê de as pessoas necessitarem "disputar postos de trabalho" entre si, em lugar de compartilhá-los, especialmente através das TIC.

\section{Vinheta 2}

Nos mais de dez telecentros de que dispõe em diversos estados ${ }^{18}$, os quais são abertos às comunidades locais, independentemente da participação da população nas ações coletivas do movimento, o MST (Movimento

17 No caso presente, tentou-se utilizar o navegador Firefox, versão 2.0.0.14.

18 Fonte: Revista A Rede, Edição n ${ }^{\circ} 8$ - novembro/2005. 
dos Trabalhadores Rurais Sem Terra) realiza atividades de capacitação para o uso das novas tecnologias e de formação de lideranças na área de inclusão digital. É importante ressaltar que, nessa iniciativa, assim como no grosso das iniciativas governamentais (federais) de inclusão digital, reserva-se um papel estratégico para a capacitação dos usuários no o uso de software livre $^{19}$, em especial do sistema operacional Linux, construído colaborativa e voluntariamente por programadores e pesquisadores do mundo inteiro conectados em rede, e disponibilizado gratuitamente a todos que por ele se interessarem na WWW.

Os excertos 3 a 5 foram retirados do manual metodológico para o Curso de Inclusão Digital oferecido por um dos telecentros do MST (Frente Digital 2004). As ênfases foram adicionas por mim:

\section{Excerto 3}

Valores humanistas e socialistas: cultivar e recuperar os valores humanos como a solidariedade, a lealdade, o espírito de sacrifício pelo bem estar do coletivo, o companheirismo, a sobriedade, a disciplina, a indignação diante das injustiças, a igualdade, a humildade, numa sociedade que dia a dia se degenera nos contravalores do individualismo, do consumismo, da apatia social, do descompromisso com a vida. (p. 1, item "projeto educativo libertador e valores"; itálicos no original)

\section{Excerto 4}

As idéias só são revolucionárias quando transformam a realidade. A capacitação e qualificação devem atingir as pessoas de maneira geral, desenvolvendo os diferentes aspectos da pessoa humana, contribuindo para a construção de uma nova ética, que oriente o comportamento dos seres humanos baseados na vivência dos valores como a solidariedade, amor à causa do povo, o companheirismo, a disciplina consciente, a responsabilidade, que vão dando forma ao novo homem e à nova mulher que almejamos alcançar, eliminando os vícios do capitalismo. (p. 1, item "cursos").

19 Software livre é um software cujo código fonte é mantido aberto ao usuário pelo seu desenvolvedor, de modo que qualquer pessoa possa usá-lo, estudá-lo, alterá-lo e distribuí-lo livremente, independentemente de obter ou não alguma vantagem financeira com isso. A única restrição imposta ao usuário desse tipo de software é que, ao fazer modificações no programa e/ou redistribuí-lo, ele deverá necessariamente manter essas mesmas liberdades para os demais usuários. 


\section{Excerto 5}

Todos nós fomos educados para uma cultura individualista na sociedade capitalista, onde nossa vontade pessoal, nosso bem estar individual estão acima de qualquer coisa. Daí nasce os desvios do individualismo, do oportunismo e do egoísmo, que minam a prática da disciplina. É necessário, pois, superar os desvios, e nos ajustar às normas, regras e objetivos principais da organização à qual pertencemos. (p. 3, item "tempos educativos", sub-item "disciplina")

Completam essa vinheta os excertos 6 a 8, retirados da "Carta do $5^{\circ}$ Congresso Nacional do MST" (MST 2007), realizado em Brasília, em junho de 2007, que expressa os compromissos que a organização vê como sendo seus em relação aos problemas da sociedade brasileira.

Excerto 6

Articular com todos os setores sociais e suas formas de organização para construir um projeto popular que enfrente o neoliberalismo, o imperialismo e as causas estruturais dos problemas que afetam o povo brasileiro (item 1 da carta).

\section{Excerto 7}

Combater as empresas transnacionais que querem controlar as sementes, a produção e o comércio agrícola brasileiro, como a Monsanto, Syngenta, Cargill, Bunge, ADM, Nestlé, Basf, Bayer, Aracruz, Stora Enso, entre outras. Impedir que continuem explorando nossa natureza, nossa força de trabalho e nosso país (item 6 da carta).

\section{Excerto 8}

Lutar para que cada assentamento ou comunidade do interior tenha seus próprios meios de comunicação popular, como por exemplo, rádios comunitárias e livres. Lutar pela democratização de todos os meios de comunicação da sociedade contribuindo para a formação da consciência política e a valorização da cultura do povo (item 16 da carta).

\section{Comentário:}

Observa-se aqui, como esperado, um forte contra-ponto às concepções de inclusão e de capacitação que transparecem da vinheta 1. Em primeiro lugar, o foco dessa agência de letramento digital na utilização do 
software livre demonstra a ênfase na propriedade intelectual do software como pressuposto para a inclusão digital que a agência anterior tenta afirmar. Em segundo lugar, embora ambos, Microsoft e MST, apostem nas TIC como instrumento para uma mudança de cenário no país, os cenários que têm em mente são bastante diferentes.

Em lugar da disputa por postos de trabalho, enfatiza-se, nessa segunda vinheta, o bem estar do coletivo e o companheirismo. Em lugar da redução da diferença educacional e social (pela via da qualificação dos mais pobres), prega-se aqui a valorização da cultura popular (excerto 8). Juntese a esses fatores o posicionamento explícito do MST contra o neoliberalismo e as empresas transnacionais (excertos 6 e 7), e facilmente poderemos situar essas duas agências de letramento digital nos pólos hegemônico e contra-hegemônico dos discursos sobre a inclusão (digital).

Note-se, contudo, que estar em pólos opostos implica também compartilhar um eixo comum. Nesse caso, compartilha-se a idéia de que a inclusão está necessariamente subordinada a alguma forma de disciplina, e à adesão, consciente ou não, a um projeto estratégico de transformação das pessoas e dos contextos que privilegia o que a tecnologia pode fazer por elas/eles, em lugar do que eles/elas podem fazer com ou sem a tecnologia por si mesmos. Também parece ser comum às duas agências a noção de que certos sujeitos, mais conscientes, podem/devem prescrever os caminhos de conscientização e emancipação (ou da subalternidade e da alienação) dos outros, menos conscientes.

\section{Vinheta 3}

Nessa vinheta ${ }^{20}$ mudo o foco: da agência passo ao ator; da instituição, ao sujeito; da conscientização à invenção. Falo de um estilista, de alguém que, embora enredado na trama dos discursos hegemônicos e contra-hegemônicos da inclusão digital, constitui-se como indivíduo singular em busca de seu acabamento via diálogo com as TIC. Falo de letramentos que se entrelaçam, em configurações provisórias, mas que permanecem abertos em seu sentido, porque conectados de maneiras que escapam a polarizações do tipo escolar versus paroquial, digital versus tradicional, alfabético versus visual, e assim por diante.

20 Retirada do capítulo 6 de Buzato (2007a). 
Conheci W., dez anos de idade, estudante do ensino fundamental, durante uma pesquisa de cunho etnográfico realizada em um telecentro público localizado na periferia da cidade de Guarulhos, região metropolitana de São Paulo, no ano de 2007. Ao abordá-lo pela primeira vez, encontrei-o pesquisando imagens no Google ${ }^{21}$, a partir da expressão-chave "carros envenenadíssimos". Como outras crianças freqüentadoras, W. costumava fazer pesquisas escolares no telecentro, mas não naquele evento específico. Quando lhe perguntei o que fazia com as imagens de carros que obtinha em resposta à sua consulta, W. retrucou "pesquiso o nome deles". Dentre as imagens obtidas, selecionava as que mais lhe agradavam, e, clicando sobre elas, era levado a algum site no qual descobria o nome do carro em questão. Em nova busca de imagens, utilizando agora o nome de um carro específico de cuja imagem lhe agradara, obtinha informações detalhadas, fotos de diversos ângulos e partes específicas do automóvel, desenhos técnicos, gráficos de desempenho, e assim por diante. Avaliei que, diferentemente das demais crianças que realizavam, naquele mesmo momento, naquele mesmo espaço, suas pesquisas escolares, W. parecia ter compreendido o potencial do buscador de imagens para desenvolver um tipo específico de prática de pesquisa, que, diferentemente da normalmente pedida pela escola, combinava fruição estética, conhecimento técnico/factual sofisticado, e capacidades letradas diversas, a partir de um interesse pessoal da criança, e de um objeto fronteiriço: o site de buscas Google.

W. percebera, a partir da experimentação livre, embora fundamentada em conhecimentos e scripts que trazia de outros contextos, o melhor potencial do buscador de imagens, em relação ao textual, para a coleta e desambiguação do tipo de informação que lhe interessava, e, ao praticá-lo dessa forma, transformou o Google numa espécie de enciclopédia visual ad hoc.

\section{Comentário:}

Quando lhe perguntei o que fazia com as imagens e textos que obtinha, W. explicou que não imprimia, catalogava ou sequer anotava coisa alguma, pois sabia ser possível recuperar tais informações facilmente, quando quisesse, através do buscador, utilizando as novas palavras-chave que aprendia a cada consulta. Dito de outra forma, o que guardava para si eram apenas índices o que levariam, a qualquer tempo, em qualquer lugar em que houvesse um computador conectado, a conteúdos constantemente renovados, expandidos e tornados mais complexos na própria rede. Seu tra-

21 Google é a mais poderosa e mais popular ferramenta de buscas na WWW. Trata-se de um software proprietário que, diferentemente de outros, pode ser utilizado gratuitamente e por meio de qualquer programa de navegação e qualquer sistema operacional, seja ele proprietário ou livre. 
balho de pesquisa não era contar o que estava na WWW em suas próprias palavras para alguém: era buscar na WWW, por meios diversos, as palavras do outro que contavam para ele mesmo. W., ao que parece, estava incluído no diálogo, havia achado ali, por meio das TIC e de uma rede de letramentos, seu acabamento provisório.

\section{As três concepções}

O que as vinhetas 1, 2 e 3 tentam ilustrar é que existe a necessidade de se pesquisar, e talvez de se fomentar através de agências, tais como a escola, toda uma gama de letramentos (digitais) e de concepções sobre inclusão (digital) que permanecem abertas, em trânsito e não capturáveis pelos grandes discursos (sejam eles hegemônicos ou contra hegemônicos), justamente porque mais sintonizadas com a complexidade do processo sócio-histórico corrente, e com as potencialidades das tecnologias disponíveis em nossos dias.

A concepção de inclusão digital ilustrada na vinheta 1, aquela que talvez goze de maior prestígio no senso comum, estende ao LD a perspectiva ortodoxa da relação entre letramento e inclusão que resultou dos processos de normalização, quantificação, e graduação valorativa impostos pela escolarização sobre os letramentos sociais ao longo da história do Estadonação, mas agora com vistas a atender novas necessidades práticas do capitalismo transnacional. Essa alternativa acarreta uma noção de inclusão (digital) como ajustamento e/ou conformação às estruturas de poder, às formulações de inclusão impostas a partir do centro e do alto, e às desigualdades vigentes e vindouras do capitalismo; e continua a depositar no sujeito individual e/ou nos grupos periféricos, o estigma da disfuncionalidade, o ônus da capacitação/requalificação e da inconsciência sobre seus próprios problemas e interesses.

Uma segunda concepção estratégica, frontalmente oposta à primeira, visa fomentar a apropriação crítica das TIC como forma de auto-afirmação cultural e de conscientização e mobilização político-ideológica para a construção do socialismo. Tal visão coaduna-se com uma perspectiva da educação voltada para a ampliação de uma consciência contra-hegemônica, e acarreta uma noção de inclusão digital como um processo de emancipação político-ideológica do sujeito que combina tecnologia e pensamento crítico. Ocorre que, tal qual a primeira concepção, essa parece querer que a 
emancipação do sujeito se faça da forma prescrita e disciplinada pelos já supostamente mais conscientizados. Nesse sentido, parece apontar para um cenário de inclusão incongruente com as possibilidades de reconfiguração das subjetividades num espaço de liberdade e de trânsito, e com a própria transculturalidade que caracteriza a era dita pós-nacional.

Há, ainda, uma terceira concepção para a inclusão digital que, embora não se possa, a rigor, chamar de estratégica ${ }^{22}$, se apresenta como significativa especialmente nas zonas periféricas das cidades globalizadas do terceiro mundo. Neste terceiro sentido, a inclusão digital não é um estado de adequação às novas estruturas de poder e, tampouco, o resultado da aplicação da racionalidade crítica a formas organizadas e disciplinadas de conscientização e resistência, mas, sim, um processo criativo, aberto, conflituoso e dialógico pelo qual grupos subalternos se apropriam das TIC de forma não prescrita por outrem.

A forma de implementação dessa terceira concepção não é delineável, porque trata-se, essencialmente, de um trânsito, uma zona de fronteira, um diálogo inconcluso. Também, essa concepção não está associada formalmente a qualquer agência de letramento, hegemônica ou contra-hegemônica, nem creio que possa ser disciplinada por alguma delas, mas, certamente, tem sido posta em prática silenciosamente pelos milhões de sujeitos que obtém acesso às TIC por meio do consumo privado e/ou dos diferentes canais de acesso público que já existem no país (a escola, o trabalho, pontos de cultura, telecentros, etc.). Tal construção pode, certamente, ser assumida, conscientemente, pelos próprios sujeitos como uma forma de emancipação, mas, em contrapartida, tal assunção lhes custará, imediatamente, a consciência de estar em num espaço agonístico. Como em todo espaço desse tipo, paga-se um preço alto por pertencer e não pertencer, saber e não saber, ser e não ser ao mesmo tempo, e, portanto, não se sabe por quanto tempo, ou a que custo, essa "abertura" consciente se mantém. Trata-se, de qualquer forma, de uma situação cada vez mais "normal” para os sujeitos contemporâneos e, portanto, de algo ao mesmo tempo útil e fascinante para quem pesquisa.

\footnotetext{
22 Tendo em vista a distinção entre estratégia e tática proposta por Certeau (1984), que não será aqui discutida, mas simplesmente respeitada. Para uma discussão sobre as implicações dessa distinção conceitual na inclusão digital, ver Buzato (2007a).
} 
O que se pode dizer, à guisa de conclusão deste trabalho, é que, se nunca foi ético prescrever a inclusão do outro, uma perspectiva sóciohistórica da relação entre inclusão, tecnologia e letramento deixa claro que, tampouco, isso é mais factível agora do que antes. Logo, o que parece caber ao pesquisador (assim como ao educador e ao formulador ou implementador de políticas públicas de inclusão digital) é muito menos legitimar formas de incluir que se traduzam em métodos para adequar sujeitos supostamente passivos ou determinados pelo sistema às novas demandas do capitalismo globalizado; e, muito mais, compreender e fomentar os modos pelos quais os sujeitos podem usar as TIC para definir e implementar suas próprias demandas (éticas, políticas, culturais, etc.), assim como para conhecer e aprender a respeitar as demandas do outro, num diálogo que será sempre inconcluso, mas, nem por isso, necessariamente, frustrante. Em suma, há que se pensar em uma ética do deixar fluir, transitar, conectar, como pressuposto para uma cidadania que preceda qualquer forma de territorialidade, lealdade ou capacitação. Isso, é claro, caso se queira, de fato, pensar em transformação.

Recebido em novembro de 2006. Aprovado em abril de 2008.

E-mail: marcelo.buzato@gmail.com

\section{REFERÊNCIAS BibLIOGRÁFICAS}

Anderson, Benedict. 1983. Comunidades Imaginadas - Reflexões sobre a Origem e a Expansão do Nacionalismo. Lisboa: Edições 70.

Barton, David. 1994. Literacy: an Introduction to the Ecology of Written Language. Oxford: Blackwell.

Bolter, Jay David. D. 1998. Hypertext and the Question of Visual Literacy. In: David Reinking, Michael C. McKenna, Linda D. Labbo \& Ronald D. Kieffer. Eds. Handbook of Literacy and Technology: Transformations in a Post-typographic World. Mahwah, NJ: Erlbaum: 3-13. . 1993. Writing Space: The Computer, Hypertext, and the History of Writing. Hillsdale, NJ: Lawrence Erlbaum.

Bourdieu, Pierre. 1986. The Forms of Capital. In: John G. Richardson Ed. Handbook of Theory and Research for the Sociology of Education. New York: Greewood Press: 241-258.

Bourdieu, Pierre \& Jean-Claude Passeron. 1977. A Reprodução: Elementos para uma Teoria do Sistema de Ensino. Rio de Janeiro: Francisco Alves. 
BuZATo, Marcelo El Khouri. 2007a. Entre a Fronteira e a Periferia: linguagem e letramento na inclusão digital. Tese (Doutorado em Lingüística Aplicada). Instituto de Estudos da Linguagem, Universidade Estadual de Campinas.

. 2007b. Letramentos Multimodais Críticos: Contornos e Possibilidades. Crop (FFLCH/USP), v. 12: 108-144, 2008.

. 2007c. Desafios empírico-metodológicos para a pesquisa em letramentos digitais. Trabalbos em Lingüística Aplicada, 46: 45-62. . 2008. Práticas Fronteiriças na Inclusão Digital. Mímeo (Projeto de pesquisa apresentado à Universidade Federal da Grande Dourados).

BAKTHIN, Mikhail Mikhailovich. 1988. Questões de Literatura e de Estética: a Teoria do Romance. São Paulo: UNESP/Hucitec. . 2003. Estética da criaşão verbal. São Paulo: Martins Fontes.

Braga, Denise Bértoli. 2004. A comunicação interativa em ambiente hipermídia: as vantagens da hipermodalidade para o aprendizado no meio digital. In: Luiz Antonio Marcuschi \& Antonio Carlos Xavier. Orgs. Hipertexto e Gêneros Digitais: Novas Formas de Construção do Sentido. Rio de Janeiro: Lucerna.

Castells, Manuel de. 1999. A Sociedade em Rede. A Era da Informação: Economia, Sociedade e Cultura, vol.I. São Paulo: Paz e Terra.

Certeau, Michel de. 1984. A invenção do cotidiano 1: artes de fazer. $5^{a}$. ed. Petrópolis, RJ: Vozes.

Collins, James \& Richard Blot. 2003. Literacy and literacies: Texts, Power and Identity. New York: CUP.

Coscarelli, Carla Viana \& Ana Elisa Ribeiro (Orgs.) 2005. Letramento Digital: Aspectos Sociais e Possibilidades Pedagógicas. Belo Horizonte: Autêntica.

Epstein, Mikhail. 2005. On the concept of transculture. Re-placing Cultures, an Inter-disciplinary and Inter-world Area Conference of Research, Emory University, Atlanta, January/2005. Disponível [http:/ /www.icis.emory.edu/replacing_cultures/On\%20the\%20Concept $\% 20$ of\%20Transculture-\%20M.\%20Epstein.pdf], 15/10/2006.

Foucault, Paul-Michel. 1977. Vigiar e Punir. Petrópolis, RJ: Vozes.

Frente digital. 2004. Metodologia: Curso de Inclusão Digital. Ceforma/ ES, Outubro 2004. Disponível em < http://id.bsb.mst.org.br/doc/ IMG/pdf/metodologia-2.pdf>, acesso em 05 jun 2008.

GeE, James Paul. 2000. The New Literacy Studies and the Social Turn. In: David Barton, Mary Hamilton, Roz Ivanic (Eds.) Situated Literacies: 
Reading and Writing in Context. London: Routledge. Disponível [http:/ /www.schools.ash.org.au/litweb/ page300.html], 12/01/2005.

Glister, Paul. 1997. Digital Literacy. New York: John Wiley \& Sons.

GIDDENS, Anthony. 1991. As conseqüências da modernidade. São Paulo: UNESP. Habermas, Jurgen. 2002. A Inclusão do Outro: Estudos de Teoria Política. São Paulo: Edições Loyola.

Hall, Stuart. 2003. Da diáspora: Identidades e Mediações Culturais. Belo Horizonte: Ed. UFMG; Brasília: Representação da UNESCO no Brasil. .2005. A identidade Cultural na Pós-modernidade. Rio de Janeiro: DP\&A.

HeAth, Shirley Brice. 1983. Ways with Words. Cambridge: CUP.

Kleiman, Angela Bustos. 1995. Modelos de letramento e as práticas de alfabetização na escola. In: Angela Bustos Kleiman (Org.) Os Significados do Letramento: Uma Nova Perspectiva sobre a Prática Social da Escrita. Campinas: Mercado de Letras.

Kieiman, Angela Bustos \& Josenia Antunes Vieira. No prelo. O impacto identitário das novas tecnologias da informação e comunicação (Internet) In: Maria José Coracini \& Izabel Magalhães. (Orgs.) GTANPOLL: Questões Identitárias.

Komesu, Fabiana C. 2005. Pensar em hipertexto. In: Julio César Araújo \& Bernardete Biasi-Rodrigues (Org.) Interação na internet: novas formas de usar a linguagem. $1^{\mathrm{a}}$. ed. Rio de Janeiro: Lucerna, p. 87-108.

Kostogriz, Alex. 2004. Rethinking the spatiality of literacy practices in multicultural conditions. The annual conference of the Australian Association for Research in Education, Melbourne, Vic. Disponível [http://www.aare.edu.au/04pap/ kos04610.pdf] 17/09/2005

Kress, Gunther. 2005. Gains and losses: New forms of texts, knowledge, and learning. Computers and Composition 22: 5- 22.

Lankshear, Colin \& Michele Knobel. 1998. Critical literacy and new Technologies. American Educational Research Association Annual Conference. San Diego, April/1998. Disponível [http:// www.geocities.com/c.lankshear/critlitnewtechs.html] 12/07/2004.

Landow, George P. 1997. Hypertext 2.0. The Convergence of Contemporary Critical Theory and Technology. Baltimore: John Hopkins University Press

LEAnder, Kevin \& Sheehy McKIm. 2003. Tracing the everyday 'sitings' of adolescents on the internet. Education, Communication and Information, v.3, n.1, p.11-30, 2003. Disponível em: < http://www. vanderbilt.edu/ litspace/ sitings.pdf $>$. Acesso em: 10 ago 2005. 
LemKe, Jay. 1998. Metamedia literacy: Transforming meanings and media. In: David Reinking, Michael C. McKenna, Linda D. Labbo \& Ronald D. Kieffer (Eds.) Handbook of Literacy and Technology. Mahwah, NJ: Lawrence Erlbaum.

LÉvy, Pierre. 1999. Cibercultura. São Paulo: Editora 34.

Maingeneau, Dominique. 1995. O Contexto da Obra Literária. S. Paulo: Martins Fontes.

Manovich, Lev. 2001. The Language of New Media. Cambridge, Mass.: MIT Press.

Marcuschi, Luiz Antonio. 2005. Da Fala para a Escrita: Atividades de Retextualização. SP: Cortez \& Antonio Carlos Xavier. 2004. (orgs) Hipertexto e Gêneros Digitais: Novas Formas de Construção do Sentido. Rio de Janeiro: Lucerna.

MST. Carta do $5^{\circ}$ Congresso Nacional do MST. 2007. Disponível em $<$ http://www.mst.org.br/mst/pagina.php?cd = 3713, acesso em 05/06/ 2008.

Palácios, Marcos \& Luciana Mielniczuk (s/d) Considerações para um estudo sobre o formato da notícia na Web: o link como elemento paratextual. Disponível [http://www.facom.ufba.br/ciberpesquisa/palacios/ compostextofinal.doc]. 12/05/2004

PAPERT, Seymour. 1980. Mindstorms: Children, Computers, and Powerful Ideas. New York: Basic Books.

Reding, Viviane. 2006. European Union, Latin America and the Caribbean: time to join forces and push for digital inclusion. IV EU - Latin America and Caribbean Ministerial Information Society Forum. Lisbon, April 2006. Disponível [http://ec.europa.eu/comm/commission_barroso/ reding/ docs/speeches/lisbon_20060428.pdf], 01/07/ 2006.

SCRIBNER, Sylvia \& Michael Cole. 1981 . The Psychology of Literacy. Cambridge, MA: Harvard University Press.

Selfe, Cynthia. 1999. Technology and Literacy in the Twenty-First Century. Carbondale: Southern Illinois University Press.

Silverblatt, Art .1995. Media Literacy: Keys to Interpreting Media Messages. Westport: Praeger.

SNyder, Ilana. 1997 (Ed.) Page to screen: Taking Literacy into the Electronic Era. St Leonards: Allen \& Unwin.

SoARES, Magda. 2002. Novas Práticas de Leitura e Escrita: Letramento na Cibercultura. Educ. Soc., 23 (81): 143-160. 
Street, Brian. 1984. Literacy in Theory and Practice. Cambridge: Cambridge University Press.

. 1988. Literacy practices and literacy myths. In: Roger Saljo (Ed.) The Written Word: Studies in Literate Thought and Action. Springer: Verlag Press.

.2003. What's "new" in New Literacy Studies? Critical approaches to literacy in theory and practice. Current Issues in Comparative Education, 5 (2). Disponível [http://www.tc. columbia.edu/cice/articles/ bs 152.htm]. 20/06/2004.

Takahashi, Tadao. (Org.) 2000. Sociedade da Informação no Brasil: Livro Verde. Brasília: Ministério da Ciência e Tecnologia. Disponível [http:/ /www.mct.gov.br/Temas/Socinfo/_Livro_Verde/livroverde.pdf]. 15/01/ 2005.

Welsch, Wolfgang. 1999. Transculturality - the Puzzling Form of Cultures Today. In: Mike Featherstone \& Scott Lash. (Ed.) Spaces of Culture: City, Nation, World. London: Sage.

Wenger, Etienne. 1988. Communities of practice: learning, meaning, and identity. New York: Cambridge University Press. 